\title{
幼小児滲出性中耳炎の聴力変化について
}

一高気压療法での観察一

石川 紀彦・大久保 仁 $\cdot$ 渡辺 勈
橴沢 三伸・枝松 秀夫 - 寺邑 公子
石田 博義 $\cdot$ 栗田 宣彦 $\cdot$ 苦瓜 知彦

Hyperbaric Therapy of Otitis Media in Ghildren

\author{
Norihiko Ishikawa, Jin Okubo, Isamu Watanabe, \\ Mitsunobu Shibusawa, Hideo Edamatsu, Kimiko Teramura, \\ Hiroyoshi Ishida, Nobuhiko Kurita and Tomohiko Nigauri
}

(Tokyo Medical and Dental University)

Secretory otitis media occurs most frequently in infancy. Since the Eustachian tube functions differently in children and adults, it is considered unlikely that secretory otitis media in the two age groups is due to the same cause. Since the infantile Eustachian tube is a kind of pressure open type, we preffered high-pressure therapy in the treatment of secretory otitis media in children.

We used high-pressure therapy for 111 children aged 3 to 12 years (188 ears) with secretory otitis media. As a result, 129 ears $(68.6 \%)$ showed improved average hearing levels within $10 \mathrm{~dB}$ in the low, medium, and high tone ranges. No patient experienced earache or other trouble when exposed to high-pressures. In the highpressure therapy, air escapes through the Eustachian tube when the middle ear pressure is regulated. In this case, the fluid can be excreted together with the air. Since the partial pressure of oxgen rises with the pressure, it is estimated that the high-pressure therapy favorably affects ciliary movement and restores the mucous menbranes in the tympanic cavity and the Eustachian tube.

Key words: hyperbaric therapy, secretory otitis media in children, the Eustachian tube

はじめに

滲出性中耳炎の好発年跉は, 幼览期之壮年期 の二峰性を示すが，ての二峰をなす幼侍期と北: 年期の発症の誘因が全く同じであるとは考えに くい. 幼小児滲出性中耳炎患者の約 $80 \%$ は, 年
歯の増加にともない自然治瘾が認められるとい う報告ああるが(1)1617，成人滲出性中耳炎に関 しては, 換気チューブ插入, 鼓膜切開や耳管通 気などの治療が行われ，耳管機能が改善されな い限り自然治瘾は望めない。しかし，幼児の患 
者で，どの症例が治癒を遷延して併発症や後遺 症を生じるかは推測しがたい，特に，本疾患 は, $3 \sim 4$ 才で発症ないしは発見される場合が 多く，乙の年代での早期保存的療法が望まれる が，乙の年代は治療に対する理解む乏しく, 非 観血療法にも抵抗して担当医を悩ませるもので ある. そこで, 小児滲出性中耳炎患者の通気法 に変わる方法として高気圧治療を考案した。 中 耳腔の含気的生理的条件を一時的に高気圧で置 換すれば，換気チューブ插入や通気に似た効果 が期待され，線毛運動の排泄機能改善にも好 影響を与える可能性があると考えたからであ $ろ^{5) 6) 7) 87}$.

\section{方 法}

本学衛生学教室所有の高圧治療用のタンクを 用いて高気圧治療を行った。 高気压の負荷プロ グラムは次の通りである．2 気压（2.0 A T A ) 環境まで，20３0分で徐々に加圧を行う，次い で， 1.7 A T A 近辺まで約 5 分で減圧し，再度 2.0 A T A 加圧を行う. この方法を数回繰り返 した後に約30分かけて常圧（1.0 A T A） に戻

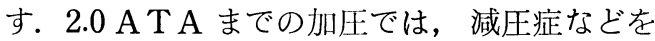
考虑する必要むなく，小児でも比較的安易に行
える，そして高気圧治療は週に 1 回で, 気導聴 カレベルが $10 \mathrm{~dB}$ 以内に改善するまで治療経過 を観察した。

\section{対 象}

対象の小児滲出性中耳炎患者は，1984～1985 年の 1 年間に本方法で治療された 111 例, 男57

表 I 高気圧治療の対象となった 111 人の年 秢, 性別. 5〜6才に多いといわれる, 他の疫学調査データーと同じ年齢分布 が茪られる。

\begin{tabular}{c|rr|r}
\hline 年粭 & 男 & 女 & 計 \\
\hline 3才 & 1 & 1 & 2 \\
4才 & 7 & 8 & 15 \\
5才 & 16 & 10 & 26 \\
6才 & 14 & 16 & 30 \\
7才 & 3 & 8 & 11 \\
8才 & 4 & 5 & 9 \\
9才 & 6 & 4 & 10 \\
10才 & 4 & 1 & 5 \\
11才 & 1 & 1 & 2 \\
12才 & 1 & 0 & 1 \\
\hline 計 & 57 & 54 & 111 \\
& & & (人)
\end{tabular}

表 2 各年耣別の, 高気圧治療に於けるオージオグラム改善度の変化（111例；188耳）

高気圧治療の各年齢別改善率を示したものである．D群のGは，口蓋裂の術後の者である.

(詳細は本文参照)

\begin{tabular}{r|r|r|r|r|r|r|r|r|r}
\hline \hline 年秢 & A1 & A2 & A3 & A4 & B & C & D & 計 & $\begin{array}{c}\text { 改善度 } \\
(\%)\end{array}$ \\
\hline 3 & 1 & & & & 1 & 1 & & 3 & 33.3 \\
4 & 6 & & & 11 & 7 & 5 & & 29 & 58.6 \\
5 & 9 & 13 & 10 & 4 & 6 & 3 & $3 \mathrm{G}$ & 48 & 75.0 \\
6 & 7 & 11 & 9 & 11 & 6 & 3 & & 47 & 80.9 \\
7 & 3 & 6 & 5 & & 5 & 1 & & 20 & 70.0 \\
8 & 2 & 3 & & & 5 & 1 & $2 \mathrm{G}$ & 13 & 38.5 \\
9 & 2 & 6 & 3 & & 2 & 4 & & 17 & 64.7 \\
10 & 1 & & 4 & & 1 & & & 6 & 83.3 \\
11 & 1 & & & & 1 & 1 & & 3 & 33.3 \\
12 & 1 & & & & 1 & & & 2 & 50.0 \\
\hline 計 & 33 & 39 & 31 & 26 & 35 & 19 & 5 & 188 & \\
& & & & & & & & (耳数) &
\end{tabular}


例，女54例，188耳である（表 1 ）。年齢は 3 才 から12才で，ピークは 5 〜才である. 患耳 は, 両側性が77例154耳, 右耳21耳, 左耳13耳 である。

\section{効果の判定}

治療経過の観察として, 一般診療の他, 主と してオージオメトリーを 1 〜 週に 1 度行な
った。オージオグラムは低音部（125，250， $500 \mathrm{~Hz})$ ，中音部 $(500,1 \mathrm{k}, 2 \mathrm{kHz})$ ，高音部 ( $2 \mathrm{k} .4 \mathrm{k}, 8 \mathrm{kHz})$ の各々の周波数領域につ いて 4 分法で平均值を求め, 治療効果の比較を 行ない, $\mathrm{A}, \mathrm{B}, \mathrm{C}, \mathrm{D}, の 4$ タイプに分け た。

Aタイプは, 聴カレベルの低, 中, 高音域が
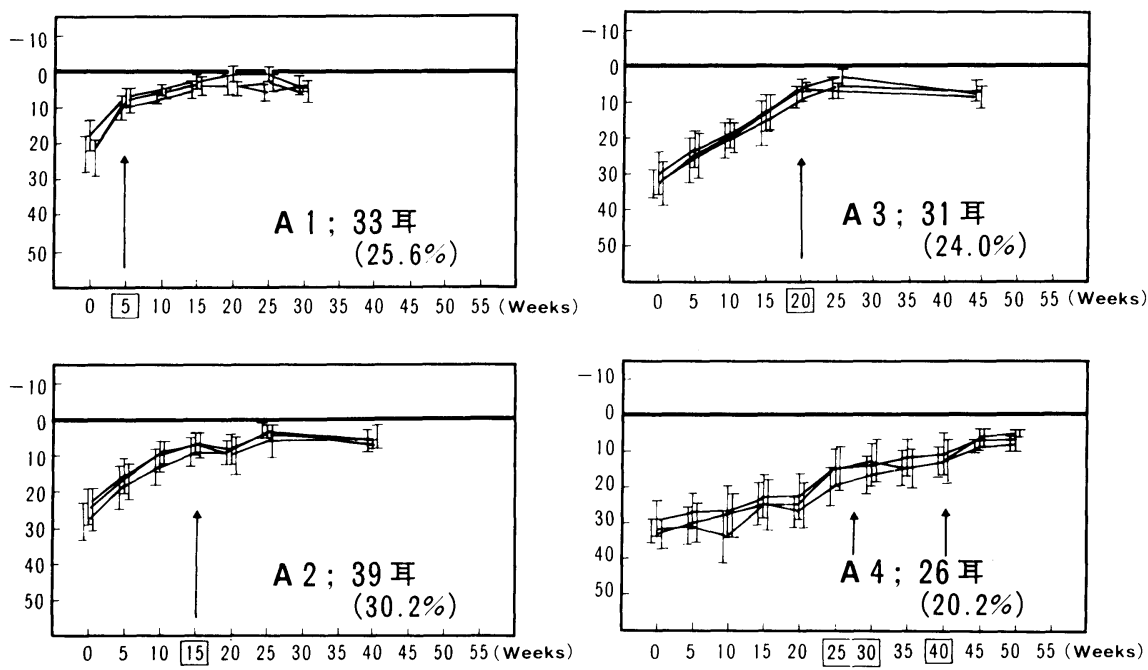

図 I $\mathrm{A}$ 群; 129 耳 $(68.6 \%)$ 亿見られる聴力改善傾向 (平均値, 標準偏差)

A群 $1,2,3,4$, の各群での改善傾向を示す. 0 週の值は, 治療前の夫 々低中高音域の平均聴力で, 矢印は $10 \mathrm{~dB}$ 以内に改善した時を示している.
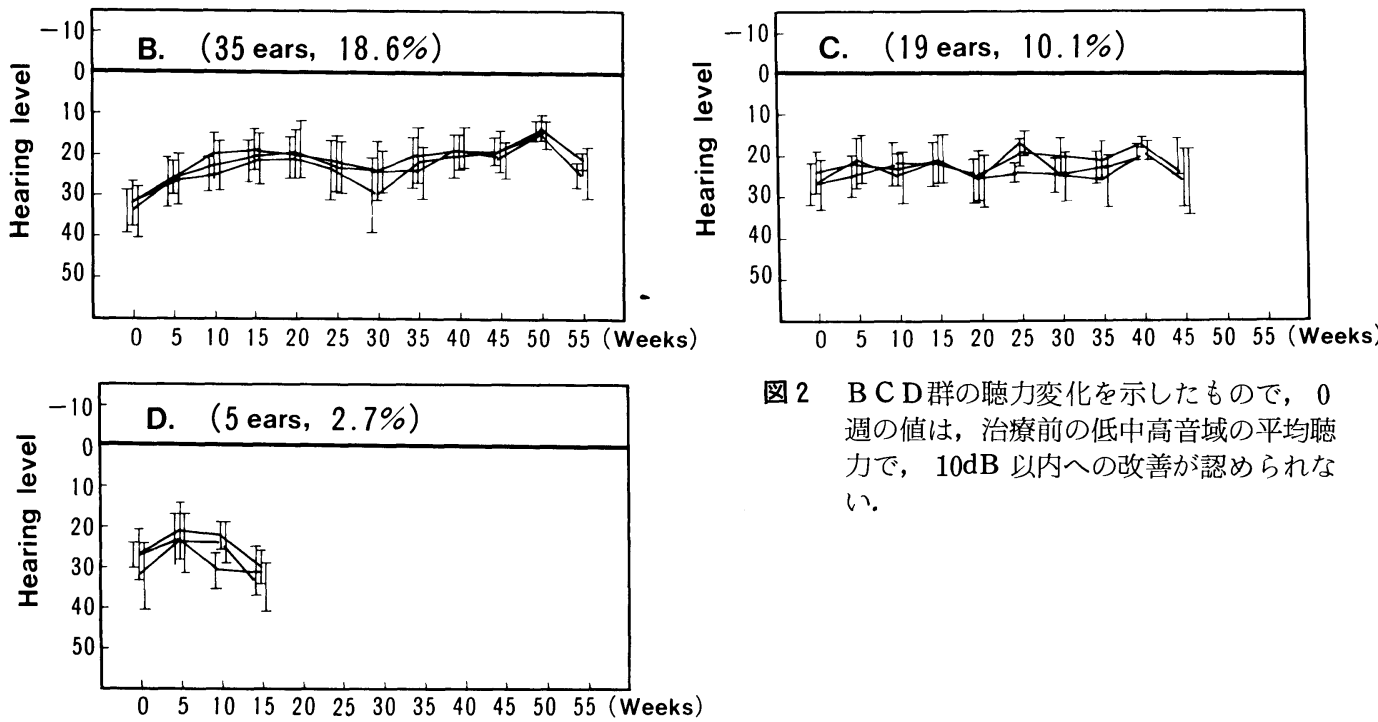

図 2 B C D 群の聴力変化を示したもので，0 週の值は, 治蟟前の低中高音域の平均聴 力で, $10 \mathrm{~dB}$ 以内への改善が認められな い. 
共に 10dB 以内に改善したもので，乙れを改善 の認められた治療日数で 4 群に分類した。

A 1 ： 5 週前後で恥力レベルが $10 \mathrm{~dB}$ 以内に 屃るもの.

A $2 ： 10 \sim 15$ 週前後で聴力レベルが $10 \mathrm{~dB}$ 以 内に戻るもの.

A $3: 20$ 週前後で聴力レベルが $10 \mathrm{~dB}$ 以内に 屃るもの.

A $4: 25$ 週以上で蚛力レベルが $10 \mathrm{~dB}$ 以内に 㞔るもの.

$\mathrm{B}$ タイプは聴力レベルが $15 \mathrm{~dB}$ 以内, 屯しく は改善倾向が認められるあの.

Cタイプは聴力レベルが不変のもの.

Dタイプは聴力レベルが恶化したもの.

\section{結 果}

これらの症例は, 純音聴力検查て気一甾導差 が会話音域で 20〜 30dB 認められ，典型的な伝 音難聴の聴力図を示した。全例の会話音域での 気㰾槙力レベルの平均值を求めると, $27.2 \pm$ 9. $6 \mathrm{~dB}$ である．鼓膜所见ししては，陷凹して貯 溜液を認め，当科受喨までに近医で鼓膜穿刺や 切開の経験のあるものが多く, tympanogram は治療前は全例 B型であった。治療成績は表 2 に示した。A群は，129耳 (68.6\%)，B群は， 35 耳 $(18.6 \%)$, C群は, 19耳 $(10.1 \%)$, D群 は， 5 耳 $(2.7 \%)$ である. 各年秢別の成績に ついてみると，5～7才の群では，総改善率の 68. 6\%より良い改善率が認められている。な お， D群の 5 例は口蓋裂の手術を受けたもので ある. 図 1 は, A 群の治瘠過程にみられたオ一 ジオグラムの改善傾向である，A群の 1,2 ,

3, 4 で改善日数が異なるが, 治療前の聴力か らは，改善度を予測させる手がかりは認められ ない，A 4 の群は25週を過ぎて次ら改善した群 で, この経過を見ると, 改善, 悪化を繰り返し ているが，約半年の経過で $10 \mathrm{~dB}$ 以内に聴力が 改善している. 図 2 は, B C D 群のオージオグ ラムの変化を示したものであるが，B群では， 現在経過を冒ているものも含まれており，少な くと屯改目倾向はみられるが $10 \mathrm{~dB}$ 以内に聴力
レベルが㞍らないあのであるが，日常の会話や 学校での生活に全く不自由はない，C群，D群 には，治療前の平均聴力が他と比べてやや悪い 傾向がみられ，治療経過で屯改善傾向が認めら れず治痳が遷延するグループの印象が強い.

\section{考按}

小児滲出性中耳炎の治療は，年齢的構成が低 く，その予後や経過が見極め難いため，治療に 当たる医師は苦労をしている，てのため，各々 の経験的立場加，非観血療法や観血療法の評 価も様々である。そして，発症の機序に関して あ, 年秢が生理的に上咽頭リンパ組織の増殖, 肥大する時期と一致するので，乙れに関連する 陰圧説 (Politzer のいう otitis media with effusion), 感染説，また，アレルギー説など 様々の要因が論じられている(12). しかし，乙 の年代は，生理的に身体条件が変動し罚く，乙 れに対して生体の合目的防御機能む自ずと備わ っていること屯想像される。

そこで，小児耳管機能の特性について考える と，この高圧治療の結果は，小児の耳管機能が 成人に比べて，压環境に順応しやすい特性を持 つものと解粎された。我々の耳管通気圧実験で 屯，幼児の耳管は成人の開放圧に比較して低い 圧で開放した。外界の異常環境に対応し易い passive opening の機能が, 生体防御機能と して，乙の時期に備わっていることが推定され る，そして，乙の機構が成長と共に失われる移 行期は10才近辺であると推定された ${ }^{10)}$ 。また， 音響耳管検査装置を用いての結果でも, 臙下運 動低存の耳管開閉持続時間は 8 才前後で成人の 耳管開放時間に近い值を示した ${ }^{18)}$ 。この様な生 理機構を利用して，非観血療法で改善させるこ とが出来れば，治癒の遷延化を低下させること あ可能である.

図 3 は, 8 才の滲出性中耳炎症例で, tympanogram C型を示すようになった頃の治療前 後に観察された tympanogram の変化であ る. 高気压治療の約 10 分後に $350 \mathrm{mmH}_{2} \mathrm{O}$ 近辺 にピークが出現し, その後 40 分頃まで斬時ピー 
クの左方移動が認められる。乙れは，乳突蜂巣 を含む中耳腔が経耳管性に陽圧置颃されたこと にほかならない，ところが，成人の滲出性中耳 炎症例にこの栐な高気压負荷を行なった場合 は, $12000 \sim 15000 \mathrm{mmH}_{2} \mathrm{O}$ 近辺で耳閉塞感と耳 痛を訴え，通気などを行ない差圧を解消する必 要が生じる。乙れは，成人の耳管機能が曣下依 存型（muscular open type）のためである. 小児の滲出性中耳炎患者が耳痛等のトラブル無 しで 2.0ATA $\left(20000 \mathrm{mmH}_{2} \mathrm{O}\right)$ 迄の加压に順
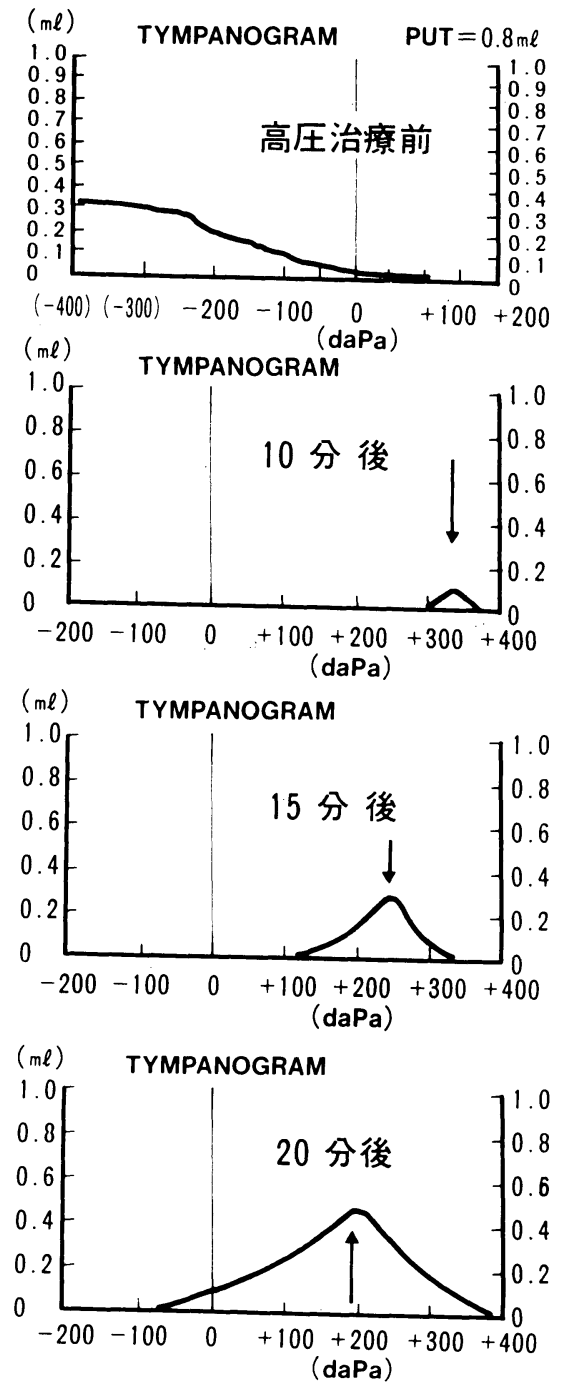

応するのは，幼览型耳管の調圧作用が，䁩下運 動にも依存するが，加，減压に対し pressure open type であることが有効に㗢く結果と考 えられる，高気圧療法は，特に，幼小児期の滲 出性中耳炎に有効な手段である.

今回の治療成績については，A群のみでは 68. $6 \%$ であったが， B群の $18.6 \%$ を非改善例と して扱わずに，乙れらを改善傾向有りとするな らば，改善率は $87.6 \%$ となり，乙の方法にも期 待が持てると考えられた。ここで勿論自然治癒
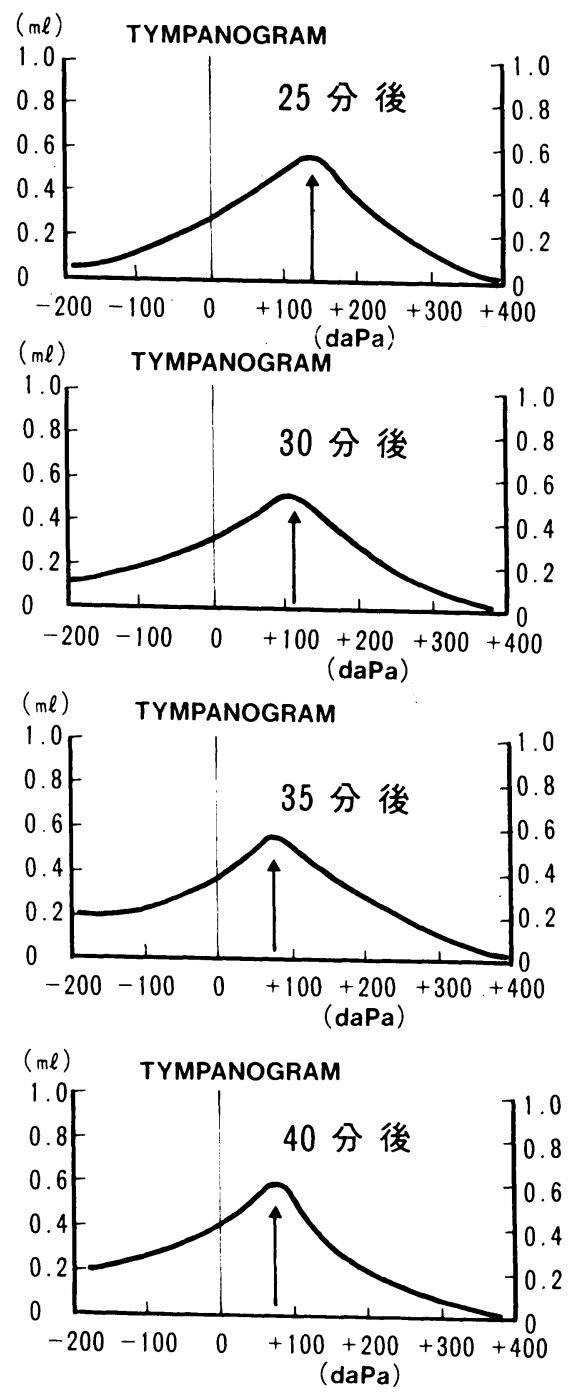

図 3 高気圧治療の前後で見られる鼓室内圧変化を経時的に記録したものである. 
の問題が考えられる. Tos ら ${ }^{115)}$ によれば幼小 児滲出性中耳炎の約 $80 \%$ に自然治癒がみられる

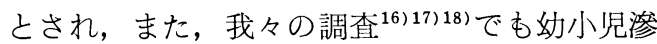
出性中耳炎の自然治癒の多さが示唆された結果 であった。しかしながら，今回の高気圧治療の 対象となったものは，既に他医で治療を受けた ことがあるものが多く，また，約 $20 \mathrm{~dB}$ 以上の 伝音難聴のあるあのであり，本治療法は有効で あったと考えられる。

我々は笑気麻酔中の実験で，笑気ガスが中耳 腔に露出し鼓室や乳㔖蜂巣圧が外気圧より約 $350 \mathrm{mmH}_{2} \mathrm{O}$ 高くなると自然に経耳管性に脱出 することを観察した。 この值は，Thomsen $(1965)^{11)}$, Patterson (1976) $)^{12)}$, Man (1980) 13)，らも 225〜 450 $\mathrm{mmH}_{2} \mathrm{O}$ であると報告したも のと一致する，乙の様な結果から，一度鼓室や 乳突蜂巣が高圧に置換されれば，幼児の場合で 屯何等の障害なく経耳管性の压脱出が行なわれ るはずである，換気チューブの挿入を全身麻酔 下で行なうと，時に鼓室内に滲出液の認められ ないものがあるが，乙れは，笑気ガスが耳管か ら脱出する際に液体排泄も行なったもので，こ の様なととからも中耳腔を圧置換するととの意 義が推測できる ${ }^{14) 15)}$.

最近, 滲出性中耳炎の治療として盛んに換気 チューブの挿入が行なわれるが，乙の目的は， 鼓室の液体排出と換気である，我々屯，高気压 療法の非改善例に換気チューブの挿入を行な い，その後，鼓室や乳㔖蜂巣の換気を目的に再 度高気圧療法を行なっているが，高気圧負荷前 には滲出液が認められなかったものでも, 治療 中や治療直後に, 外耳道への多量な液の排出が 認められるあのがある。 これは, 乳突蜂巣に貯 留したものが高気圧置換により排出されたもの と考えられた。しかし，てれらの症例に対する 詳細な検討は，今後の課題とした。 そこでこれ らの現象を整理すると，本法は通気法に似てい るが乳突蜂巣まで加圧や減圧空気で換気するて とが特徴である. 加圧に対して小児は, 耳管特 性からたやすく鼓室や乳突蜂巣が圧置換され，
減圧に際しても経耳管性に圧脱出が起こり，他 動的な耳管の開閉運動が行なわれる．また，換 気チューブの插入で鼓室の粘膜が正常化すると するならば，本法で，鼓室や乳哭蜂巣を高気圧 に置換することは，酸素分圧も高めるため，鼓 室や耳管などの線毛運動にも好影響を与える可 能性も考えられる。

\section{結語}

1）小児滲出性中耳炎の中耳腔や乳突蜂巣 を，高圧タンクを用いて一時的な高気圧置換を 行ない，オージオグラムを指標に検討した。

2) 3 才から12才の男女111名，188耳で, 低，中，高音域が $10 \mathrm{~dB}$ 以内に戻ったもの 68.6 \%であった。なお，B群と分類した群には改善 傾向が認められるが，今回は非改善例として扱 った。

3 ）各年踰群の改善度を比較すると， $5 ， 6$, $7 才 の$ 群は, 患者数む多いが改善率が総改善率 を上回った。

4 ）小児滲出性中耳炎患者は，小児の耳管機 能の特性のためか加圧や減圧に対して中耳腔の 圧置換が容易であった。しかし，10才前後から 成人型の臙下依存型の耳管機能に変化する事が 推定されるので，10才以上の場合は圧暴露に注 意を要する.

5 ）高圧治療は常圧より屯酸素分圧が高まる ことから，線毛迎動や粘膜病変に対して好影響 を与えうると推論した。

6 ）諸家により，小児滲出性中耳炎は成長に ともない約 $80 \%$ は自然治瘾するとも言われてい る.しかし，本疾患のどの例に治癒の遷延化が 起とりうるのか，現状では鑑別が困難である. このため，早期に何らかの積極的な治療を行な い，治癒遷延化を防ぐ手だてが必要である.

\section{参考文献}

1) Tos M, Poulsen G and Borch J : Etiologic factors in secretory otitis. Arch Otolaryn gol $105: 582 \sim 588,1979$.

2) Senturia BH, Gessert CF and Carr CD : 
Middle ear effusion; Causes and treatment. Trans Am Acad Opthalmol Otolaryngol 64 : 60 72, 1960 .

3) 大久保仁, 渡辺 勈, 石川紀彦, 他: 高圧環境下 の経耳管性気体脱出について。臨床耳科 $12: 58$ $\sim 59,1985$.

4 ) 大久保仁, 渋沢三伸, 阿瀬雄治, 他 : Technetium-99m pertechnetate $\left({ }^{99 n} \mathrm{ncO} 4\right)$ テクネシ ウム $(98 \mathrm{~m}$ Tc $)$ による慢性穿孔性中耳炎症例の 耳管機能検查法. 耳喉 $52: 567 \sim 573,1980$.

5) Tos M : Spontaneous improvement of secretory otitis and impedance screening. Arch Otolaryngol $106: 345 \sim 349,1980$.

6) Tos M: Middle ear epithelia in chronic secretory otitis. Arch Otolaryngol 106 : 593 597, 1980.

7 ) 大久保仁, 渡辺 勈, 石川紀彦, 他: 小児參出性 中耳炎の高気圧療法の試み。臨床耳科 $10: 234$ 235, 1983.

8 ）大久保仁：小児滲出性中耳炎の高気圧療法. 耳喉 $52 ; 857 \sim 860,1984$.

9) 大久保仁, 渡辺 勈, 石川紀彦, 他: 中耳腔内圧 変化と耳管調圧作用. 耳鼻臨床 $78: 1907$ 1915, 1983.

10）大久保仁, 渡辺 勈, 石川紀彦, 他: 音響耳管検 查法に於ける音響通気検査法の役割. 臨床耳科 II : 242 243, 1984.

11) Thomsen KA, Terkildsen $K$ and Arnfred I : Middle ear pressure variations during anesthesia. Arch Otolaryngol $82: 609 \sim 611$,
1965.

12) Patterson KE and Bartlett PC : Hearing impairment caused by intratympanic pressure changes during general anesthesia. Laryngoscope 86:399 404, 1976.

13) Man A, Segal $S$ and Ezra $S$ : Ear injury caused by elevated intratympanic pressure during general anesthesia. Acta anesthesia Scand $24: 224 \sim 226,1980$.

14) Johnson LP, Parkin JL, Stevens MH, et al : Action of general anesthesia on middle ear effusion. Arch Otolarygol 106:100 102, 1980.

15) Ostefeld E, Crispin M, Blonder J, et al : Middle ear gas composition during nitrous oxide-oxygen ventilation. Ann Otol 89: 165 167, 1980.

16）大柿 徹, 大久保仁, 渡辺 勈, 他: 那須地方幼 児, 学童のチンパノメトリーと年秢変化. 臨床耳 科 $12: 264 \sim 265,1985$.

17）大柿 徹, 渡辺 勈, 大久保仁, 他: 四季変化に 対する幼児, 学童のチンパノメトリ一変化. 臨床 耳科 13:456 457，1986.

18）石田博義, 大久保仁, 渡辺 勈, 他: 那須地方幼 児, 学童の音響耳管検査成績と年㱓変化. 臨床耳 科 $12: 56 \sim 57,1985$.

原稿採択 : 昭和 62 年 6 月 29 日 急載 別别請求先：石川紀彦 于113 東京都文京区湯島 1-5-45 東京医科歯科大学耳鼻咽喉科学教室 